\title{
CHEMICAL AND ANTICONVULSANT SCREENING OF CRINUM JAGUS.
}

\author{
M.O. Edema* and F.E. Okieimen \\ Chemistry Department, University of Benin, Benin City, Nigeria. \\ E-mail: marydema@uniben.edu
}

\begin{abstract}
Analysis of the bulbs of Crinum jagus (Thomps.) gave, in addition to lycorine and hamayne, tetrahydro - 1,4- oxazine (morpholine) as its hydrochloride, calcium oxalate and calcium tartarate.

${ }^{*}$ Author for correspondence
\end{abstract}

\section{INTRODUCTION}

The plant Crinum jagus (Thomps.) belongs to the Amaryllidaceae family. It is a bulbous plant with large leaves with parallel veination. The leaves are shining green when fresh and it has white flowers on a big stalk.

Traditional healers in Nigeria for the treatment of various ailments use it. The leaves are used in treating boils and open wounds by applying the leaf juice on the affected body part ${ }^{1}$, the leaf infusion in water is taken orally for the treatment of chronic cough that is accompanied by excessive perspiration and body pain $^{2}$; the bulb blended with Xylopia ethiopicum fruits is rubbed into incisions for the treatment of convulsion ${ }^{3}$; for the treatment of broken bones, the bulb is pounded in a wooden mortar with ripe palm nut fruits and Amaranthus spinosus leaves, the mixture is heated in an earthenware pot, cooled and tied around the affected region $^{3}$.
Adesanya et $a l^{4}$ reported that crinamine from the bulbs showed strong antibacterial activity against Bacillus subtilis and Staphylococcus aureus. Other alkaloids so far isolated from $C$. jagus include lycorine, psuedolycorine, crinamine, 6 - hydroxycrinamine and hamayne from the bulb $b^{4,5}$ and tyramine from the flower stalk ${ }^{1}$.

This paper is part of an on - going project on the phytochemical and pharmacological evaluation of some plant material that are frequently used locally as chemotherapeutic agents in the treatment of convulsion and reports on the examination of the anticonvulsant properties of $C$. jagus bulbs.

\section{EXPERIMENTAL}

\section{Plant materials}

Bulbs of C. jagus were collected from a herbal garden in Sapele, Delta State of Nigeria. They were identified at the Department of Botany, University of Benin, Benin City, Nigeria where samples were deposited. 
The bulbs were cleaned by washing off the earthy covering with water. The cleaned bulbs $(1.1 \mathrm{~kg})$ were blended in an all steel blender and extracted cold with 4.5litres of $80 \%(\mathrm{v} / \mathrm{v})$ aqueous methanol. The extract was concentrated to about $150 \mathrm{ml}$ using a rotary evaporator under vacuum. The concentrate was successively extracted with three portions each of $100 \mathrm{ml}$ petroleum ether $\left(40-60^{\circ} \mathrm{C}\right)$, ethyl acetate and n-butanol.

Each fraction was reduced to dryness under vacuum. The petroleum ether fraction was $s^{1}$ ubjected to flash column chromatography using a graded mixture of hexane and ethyl acetate $(9: 1-0: 1)$ on silica gel. Portions of $30 \mathrm{ml}$ of eluent were collected and monitored using thin layer chromatography.

Flash column chromatography of the ethyl acetate fraction was carried out using a graded solvent mixture of hexane and chloroform $(19: 1 \quad-\quad 0: 1)$ and chloroform and methanol (19:1 - 4:1). A residual band in the column was washed out of the air-dried silica using ethanol acidified with dilute $\mathrm{HCl}$.

The n-butanol fraction was subjected to preparative thin layer chromatography and the bands were purified by reverse phase HPLC.

\section{Anticonvulsant test}

20 white albino mice weighing between 20-30g were obtained from the University of Benin, Department of Pharmacology animal farm. These were randomly divided into two groups of ten mice each. A group was used for testing each isolate from $C$. jagus. Each was subdivided into four $(3,3$, and 3 as experimental and 1 as control). Varying volumes of the isolate solution were made and administered intraperitoneally to each group of mice once based on average body weight. Animals in the control group were injected with only solvent. An electroconvulsive shock therapy equipment (Ugo basile ECT UNIT 7801) was used to deliver a current of $50 \mathrm{~mA}$ for 0.2 second duration through the ear lobes. Preliminary test showed that the introduced current produced tonic forelimb and hind limb extension in the mice. The mice were tested every ten minutes from the time of drug administration.

\section{RESULT}

The petroleum ether fraction yielded an incompletely identified unsaturated long chain alcohol labeled M1. Tetrahydro - 1,4-oxazine hydrochloride was washed out of the ethyl acetate column, the n-butanol fraction yielded hamayne, lycorine and the $\mathrm{C}-6$ methoxy isomer of crinamine which under handling yielded the 3 - oxo derivative (M-2). A mixture of calcium oxalate and calcium tartarate was found in the aqueous leftover.

\section{Spectroscopic data}

EI-MS was by Autospec EI; ${ }^{1} \mathrm{H}$ and

${ }^{13} \mathrm{C}$ NMR on Buchem GX 270 with TMS as internal standard, UV spectra on a Varian UV - visible spectrophotometer and IR by FT - IR.

\section{M-1:}

M.pt. $70-72^{\circ} \mathrm{C}$. It was soluble in hot petroleum ether but slightly soluble in cold.

\begin{tabular}{|c|c|}
\hline UV & $\lambda_{\max }$ at $248 \mathrm{~nm}$. \\
\hline $\operatorname{IR}(\mathrm{KBr})\left(\mathrm{cm}^{-1}\right):$ & $3420,2920,2860$ \\
\hline $1600,1440,1170$ & 20,850 and 785 \\
\hline${ }^{1} \mathrm{H}$ NMR $\left(\mathrm{CDCl}_{3}\right)$ & $3.56(\mathrm{t}, \mathrm{J}=9 \mathrm{hz})$ \\
\hline & 3.49 (s) 1.65 (br-s), \\
\hline & $1.25(\mathrm{~s}), 0.87(\mathrm{t}, \mathrm{J}=$ \\
\hline & $\begin{array}{l}\text { 6hz) and } 0.59(\mathrm{br}- \\
\text { s). }\end{array}$ \\
\hline $\begin{array}{l}{ }^{13} \mathrm{C} \mathrm{NMR}\left(\mathrm{CDCl}_{3}\right) \\
\left(\mathrm{CH}_{2}\right), 22.73\left(\mathrm{CH}_{2}\right.\end{array}$ & $\begin{array}{l}76.54(\mathrm{C}), 31.97 \\
4.10\left(\mathrm{CH}_{2}\right) .\end{array}$ \\
\hline
\end{tabular}


GC - MS :

$325\left(\mathrm{M}^{+}\right), 281,267$, 249, 207, 193, 177, 175, 161, 147, 133, $125,113,111,97$, $95,91,87,85,71$, $69,67,57,55,43$ (basepeak), 41 .

\section{Tetrahydro - 1,4-oxazine hydrochloride} M.pt: $180.6^{\circ} \mathrm{C}$ UV

$\lambda_{\max } 205 \mathrm{~nm}$

IR $(\mathrm{KBr})\left(\mathrm{cm}^{-1}\right): \quad 3410,2992,1638$, $1572,1458,1087$, 1040 and 905.

${ }^{1} \mathrm{H}$ NMR $\left(\mathrm{CD}_{3} \mathrm{OD}\right): \quad 3.91$ (quintet, $\mathrm{J}=3-$ 2-2-3), 3.94 (quintet, $\mathrm{J}=3-2-2-3)$ and 1.2 (s, small)

${ }^{13} \mathrm{C}$ NMR $\left(\mathrm{CD}_{3} \mathrm{OD}\right): \quad 64.8\left(\mathrm{CH}_{2}\right), 44.6$ $\left(\mathrm{CH}_{2}\right)$. MS - EI

Lycorine $88(3 \%), 87(77 \%)$, $86(27 \%), 58(6 \%)$, $57(100 \%)$ and 56 (29\%).<smiles>ClC1CCOCC1</smiles>

Lycorine was identified by its m.pt, IR which corresponded to that in chemical literature ${ }^{6}$ and its MS - EI which was superimposable on that available in the database (record at the MS laboratory of the School of Chemistry, University of Bristol).

Hamayne was identified by comparing of its IR, $1 \mathrm{H}$ NMR and MS - EI to that in chemical literature ${ }^{7}$.

IR $\left(\mathrm{cm}^{-1}\right)$ : $\quad 3599,3468,3132$, 2860, 1558, 1318, 1095 and 948.

${ }^{1} \mathrm{H}$ NMR $\left(\mathrm{CDCl}_{3}\right)$ : $6.25(\mathrm{H}-2), 4.0(\mathrm{H}-$ 3), 2.19, $2.02(\mathrm{H}-4), 3.45(\mathrm{H}-4 \mathrm{a})$,

$$
\begin{aligned}
& 4.50(\mathrm{H}-6), 6.49( \\
& \mathrm{H}-7), 6.81(\mathrm{H}-10), 3.75 \\
& (\mathrm{H}-11), \\
& \multicolumn{1}{c}{3.33(\mathrm{H}-12) \text { and }} \\
& 5.91\left(\mathrm{O}-\mathrm{CH}_{2}-\mathrm{O}\right) . \\
& 287(7.56 \%), 286(3.17 \%), \\
& 269(100 \%), 240(35.14 \%), \\
& 224(20 \%), 211(22.2 \%), \\
& 181(54.47 \%), 153(18.17 \%) \\
& 115(27.55 \%) .
\end{aligned}
$$

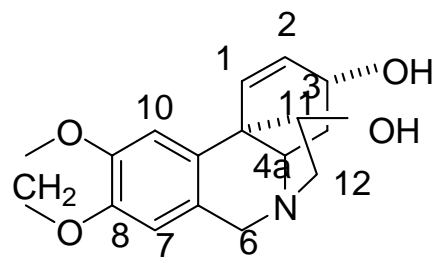

M- 2 :

The structure is possibly that of 3 -oxo derivative of 6- methoxycrinine. This was determined by comparism with reported MS fragmentation for some oxo-derivatives ${ }^{8}$.

IR $\left(\mathrm{cm}^{-1}\right)$ : $\quad 2929,1671,1526,1483$, $1422,1133,930$ and 844 .

MS - EI: $\quad 272(22 \%), 271(100 \%) 254$ (10\%), $242(10 \%), 242$ (10\%), $224(26 \%), 199$ (52\%), 187 (46\%) and 115 $(30 \%)$.

MS - CI: $300\left(\mathrm{MH}^{+} 11 \%\right), 272$ (100\%), $271(82 \%), 254$ $(100 \%), 236(24 \%)$.

${ }^{1} \mathrm{H}$ NMR $\left(\mathrm{CDCl}_{3}\right): \quad 6.62(\mathrm{H}-1), 5.98(\mathrm{H}$ $-2), 1.15(\mathrm{H}-3), 1.93,1.32$ $(\mathrm{H}-4)$

$4.3(\mathrm{H}-6), 6.7(\mathrm{H}-$ 7), $7.0(\mathrm{H}-10)$, $3.46\left(-\mathrm{OCH}_{3}\right), 4.02$ $(\mathrm{H}-4 \mathrm{a}), 4.15(\mathrm{H}-$ 12) and $5.92(\mathrm{O}-$ $\mathrm{CH}_{2}-\mathrm{O}$ ). 
<smiles>COc1cc2c(cc1OC)[C@@]13C=C[C@H](O)CC1N(CC2)C3O</smiles>

6- hydroxycrinine oxo-6-methoxycrinine (M-2)

\section{Anticonvulsant test:}

Lycorine was found to have a significant anticonvulsant effect at a concentration of $51.3 \mathrm{mg} / \mathrm{kg}$ for up to 40minutes after administration while the tetrahydro -1,4- oxazine hydrochloride, on the other hand, aggravated the induced convulsion in the mice. At a concentration of $225 \mathrm{mg} / \mathrm{kg}$, some of the animals died, as they did not recover from the seizures after the induced convulsion.

\section{DISCUSSION}

As reported by $\mathrm{Osifo}^{2}, C$. jagus leaf infusion is taken orally for cough and Ebido $^{3}$ said that it is rubbed into incisions in the patients' body for treatment. The fact that it contains tetrahydro -1,4oxazine in some form in $C$. jagus as reported in this paper thus gives cause for concern as it is implicated in causing cancer ${ }^{9}$. However, some compounds with the tetrahydro -1,4- oxazine group, for example, p-amino benzenesulphonyl morpholine, have been shown to exhibit anticonvulsant activity against electroshock and pentylene induced tonic seizures in mice ${ }^{10}$. The tetrahydro $-1,4-$ oxazine compound in $C$. jagus may be an anticonvulsant or seizure aggravating depending on the moiety to which it is bound to in the plant.
Lycorine showed some anticepulsant protection in mice and may be one of the compounds that make the plant useful as an anticonvulsant to local herbalist.

$\mathrm{OCH}_{3}$

\section{ACKNOWLEDGEMENT}

The authors are grateful to the Authority of the School of Chemistry, University of Bristol for the use of their laboratory facilities and to the World Bank for its assistance under the World Bank Staff Development Loan to Nigeria.

\section{REFERENCES}

1. Oliver, B., Medicinal plants in Nigeria. College of Arts, Science and tech. Ibadan

reports. Crown Agents London, 1959.

2 Osifo, N. G., A system of Traditional Health Care. Vol. 2 P. 11, Neraso Publisher, Benin City, 1992.

3 Ebido, S.I., Personal Communication, 1992.

4 Adesanya, S. A., Olugbade, T. A., Odebiyi, O. O. and Aladesanmi, J. A., Intern. Jour. Pharmacog. 30:40 (1992) 303.

5 Powell, J.W. and Taylor, D.A.H., J. West Afr. Sci. Asso., 12 (1967) 50.

6 Ali, A.A., Kating, H., Frahm, A.W., El - Moghanzi, A.M. and Tmadan, M.A. Phytochem. $20: 5$ (1981) 1121.

7 Ochi, M., Otsuki, H. and Nagao, K., Bull. Chem. Soc. 49 :11 (1976) 3363.

8 Duffield, A.M., Aplin, R.T., Budzikiewirz,H, Djerassi, C.,Murphy, C.F. and Wildman, W.C., J. Amer. Chem. Soc. 87 :21 (1965) 4902 .

9 Vogel, A.I., A Textbook of Practical Organic Chemistry, $4^{\text {th }}$ 